\title{
The Reaction of the Consumption of Fossil Fuels to Trade Openness in Latin America \& the Caribbean Countries
}

\author{
Matheus Koengkan $^{1}$; José Alberto Fuinhas ${ }^{2}$; Isabel Vieira ${ }^{3}$. \\ $1-\mathrm{PhD}$ in (Economics) at the University of Évora, Évora (Portugal), Masters (in Economics) from the University of Beira \\ Interior. $\mathrm{He}$ is a researcher in the areas of Latin American and the Caribbean studies, macroeconomics, energy economics \\ and environmental economics at Center for Advanced Studies in Management and Economics of the Universidade de \\ Évora (CEFAGE-UÉ). \\ $2-\mathrm{PhD}$ (in Economics) is a professor of monetary and financial economics, and intermediate econometrics at the Faculty \\ of Economics, University of Coimbra (Portugal). He is a researcher in the areas of macroeconomics and energy economics, \\ at the (CeBER) - Centre for Business and Economics Research, and (NECE-UBI) - Research Unit in Business Science and \\ Economics, sponsored by the Portuguese Foundation for the Development of Science and Technology. \\ 3 - CEFAGE-UE and Department of Economics, University of Évora, Évora, Portugal.
}

\begin{abstract}
This article investigates the impact of trade openness and renewable energy on the consumption of fossil fuels for a panel of fourteen LAC countries over the period from 1990 to 2014. To this end, a PARDL model in unrestricted error-correction form is estimated, and robustness checks are performed by estimating a PNARDL model. The results of the PARDL model point indicate that the impact of economic growth and elasticity of trade openness are statistically significant at the $1 \%$ level and contribute to increased consumption of fossil fuels in the LAC countries. However, the impact and elasticity of consumption of renewable energy are statistically significant at $1 \%$ and $5 \%$ levels and thus contribute to decreasing consumption of fossil fuels. Nevertheless, the asymmetry of the impact of consumption of renewable energy and its elasticity decrease the consumption of fossil fuels. Therefore, the positive impact of trade openness on the consumption of fossil fuels suggests that the process of globalisation by trade liberalisation in the LAC countries is not sufficient to bring more investment that encourages $R \& D$ in energy efficiency technologies, and equipment that reduces the consumption of energy from non-renewable energy sources by households and firms.
\end{abstract}

Keywords: Energy economics; Econometrics; Fossil fuels; Latin America \& the Caribbean; Macroeconomics; Trade openness.

JEL Codes: E6; F1;Q40;Q43. 


\section{Introduction}

The classical Heckscher-Ohlin theory of international trade suggests that in the context of free trade, developing countries would specialise in the production of goods that are produced with relatively abundant factors of production (for example, natural resources and labour force), while developed countries would specialise in the production of goods that are more capital and human capital-intensive. (SHAHBAZ et al., 2014). According to the same authors, trade openness is characterised by the movement of goods and services produced in one country and then further processed or consumed in another country. Indeed, without the use of energy, the production of such goods and services would not be possible. This use of energy in the production of goods and services is affected through changes in the growth of the economy (scale effect), through changes in the structure of the economy (composition effect), and through changes in the techniques and technologies that are used for production (techniques effect) (e.g., JENA and GROTE, 2008 and GHANI, 2012).

In the scale effect, liberalisation will increase economic activity because of static-dynamic gains from trade. That is, the increase in economic activity will increase energy consumption (GHANI, 2012). The composite effect of the consumption of energy depends on how the structure of the economy is affected by liberalisation. That is, this effect indicates that the use of energy-intensive changes according to the economic development, for example from agriculture to an industrial economy; this change occurs in the initial stages of economic development, where the economy is based largely on the agriculture sector, and consequently the use of energy is relatively less (SHAHBAZ et al., 2014). The same authors add yet that when the economy changes from agriculture to industrial, the use of energy increases. Moreover, GHANI (2012) adds that, in most cases, the technique effect reduces energy consumption as improvements in technology due to technology transfer improve energy efficiency. SHAHBAZ et al., (2014) also refer to this as the technique effect, when developing countries import of advanced technologies and consequently increase the production of outputs with low energy consumption.

Indeed, the scale, composition and technique effects are possible through trade openness that allows the developing countries to import advanced technologies from developed countries (SHAHBAZ et al., 2014). This process of trade openness improves the transfer of new technologies helping technological progress and brings about a consequent improvement in productivity (ZAHONOGO, 2016). This technological progress, as mentioned before, consists of intermediated manufactured products, capital equipment, technological goods, electronic equipment, and new material that are commercialised in international markets, where it allows countries to import the R\&D done by other countries (HENRY et al., 2009). 
Moreover, ZAHONOGO (2016) adds yet that this consensus rests on the assumption that trade creates economic incentives that boosts productivity, where trade reduces misallocation of resource use in the short run, and in the long run facilitates technology transfer among countries.

Therefore, this technology transfer by international trade takes on even greater importance for productivity growth in developing countries, as this group undertakes little domestic R\&D and therefore has few domestic sources of new technology (HENRY et al., 2009). According to COE et al. (1997) thane increase of $1 \%$ in the Research and Development $(R \& D)$ capital stock in industrialised countries raises the output in developing countries by $0.06 \%$. This evidence makes it clear that the importance of international trade is substantial for developing countries.

Moreover, energy affects trade openness in various ways. First, the energy is an important production factor, where the equipment and machinery in the process of production require energy. Second, the exports and imports of manufactured goods or raw material require energy for fuel transportation (SHAHBAZ et al., 2014). For this reason, the study of this relationship is essential.

This is different from the relationship between economic growth and consumption of energy that started to be investigated in the 1970s by KRAFT and KRAFT (1978). The study of the relationship between trade openness and the consumption of energy has a different trajectory. This topic is very recent, with the first study investigating this relationship produced by COLER (2006). The author explored this relationship in 91 high-, middle- and low-income countries in the period 1980-2010. The empirical results of their study pointed to the existence of a feedback effect between trade openness and energy consumption.

Despite the initiative of COLER (2006) in realising the first investigation about the impact of trade openness on the consumption of energy, this topic still has not received much attention from researchers, and the scarcity of academic studies impairs understanding of how trade openness and consumption of energy, in fact, interact with each other (KOENGKAN, 2018d).

In the Latin America \& the Caribbean (LAC) countries, the consumption of energy has more than doubled in the last 40 years. However, this growth has not been constant (KOENGKAN et al., 2019b). Indeed, it was in the 1970s that the consumption of fossil fuels proliferated, as the economic activity and trade openness of the region grew greatly (KOENGKAN et al., 2019b). 
From the 1980 s to the 1990 s, the economic activity of the region entered into decline with the debt crisis that led the economy of Latin American countries into deep recession followed by a slow recovery (KOENGKAN et al., 2019a). It was also in this period that, according to TISSOT (2012), the consumption of energy from non-renewable sources rapidly expanded in the region, while the consumption of energy from renewable sources declined.

The prominence of non-renewable energy sources in the energy matrix of LAC countries derives from the fact that some countries are ranked among the most significant oil producers in the world, i.e., Argentina, Brazil, Colombia, Mexico, Venezuela (RB), Ecuador, and others are significant importers, i.e., Brazil, Chile, Dominican Republic, Uruguay, and Paraguay (FUINHAS et al., 2017). These countries are benefiting from plunging oil prices because they will have to pay less for their oil imports, as well as some places where the generation of energy depends on oil products (KOENGKAN et al., 2019b). According to JURADO (2018), although Brazil is the second major oil producer in the region, the country is the biggest net oil importer as it is the top oil consumer in the LAC region. Moreover, Venezuela (RB), Brazil, Colombia, Argentina, and Ecuador are responsible for $85 \%$ of total oil production in the region (IEA, 2018).

Non-renewable energy sources accounted for $46 \%$ of the primary energy supply in the LAC region in 2013, while they averaged 31\% worldwide (KOENGKAN et al., 2019b). According to IRENA (2016), natural gas represents $23 \%$ of the primary energy consumed in the region. Despite this, the region has one of the most significant shares of renewable sources in the energy mix (KOENGKAN and SOUSA, 2019d).

The first sustained experience with trade liberalisation in the LAC region was in Chile in the 1970s, when this country became one of the most open in the entire world. In the 1980s, other countries such as Bolivia, Costa Rica, and Mexico in 1989 followed this trend and gradually opened their markets. In the early 1990s, more countries joined this movement, including Argentina, Brazil, Colombia, Peru and Venezuela (RB) (AGOSIN and FRENCH-DAVIS, 1993).

These events motivated the central question of this investigation: What is the impact of trade openness on the consumption of non-renewable energy in the LAC countries? The most specific issues resulting from this main question are:

I. What are the possible explanations for the impact of trade openness on the consumption of non-renewable energy in the LAC countries?

II. Is the process of globalisation by trade openness in LAC countries capable of decreasing the consumption of fossil fuels? 
In order to answer these questions, the effect of trade openness on the consumption of energy from non-renewable sources will be analysed using a dataset comprising data for fourteen countries from the LAC region for the period from 1990 to 2014. The Panel Autoregressive Distributed Lags (PARDL) model in the form of Unrestricted Error-Correction Model (UECM) is used as our central model estimation, and a Panel Non-linear Autoregressive Distributed Lag (PNARDL) model will be applied to check the robustness of the results. That is, the main objective of this article is to identify the effect of trade openness on the consumption of fossil fuels in the LAC countries.

\section{Materials and methods}

Section 2 is divided into two parts: (2.1) presents the materials and variables that will be used, and (2.2) describes the adopted method strategy that will be applied in this investigation.

\subsection{Materials}

To accomplish the goal of this investigation, annual data was collected from 1990 to 2014 for fourteen countries from LAC region, i.e., Argentina, Bolivia, Brazil, Chile, Colombia, Dominican Republic, Ecuador, El Salvador, Guatemala, Mexico, Nicaragua, Panama, Peru, and Venezuela (RB). Why were LAC countries used for this study? LAC countries were chosen on the grounds that: (i) they have experienced a rapid process of trade openness that started in the 1970s and intensified at the end of the 1990s; The variables which were chosen to perform the empirical analysis are:

- Fossil fuel consumption (FOC) from oil, gas and coal sources in (kWh per capita), retrieved from World Bank Open Data (2019);

- Gross Domestic Production (Y) in constant (2010 US\$) per capita retrieved from World Bank Open Data (2019);

- Renewable energy consumption (REC) from biomass, hydropower, solar, photovoltaic, wind, wave and waste in (kWh per capita), retrieved from World Bank Open Data (2019);

- Trade openness (TR) is an economic metric calculated as the ratio of the country's total trade - the sum of exports plus imports - to the country's gross domestic product., retrieved from World Bank Open Data (2019).

Trade expansion and technological development have increased energy demand in the last decade. Indeed, international trade and consumption of energy tend to move together. So, for this reason, it is necessary to learn more about the effect of trade openness on the consumption of energy. 
The variable trade openness (TR) was used by several authors (e.g., KOENGKAN, 2018d; NASREEN and ANWAR, 2014; SEBRI and BEN-SALHA, 2014; SBIA et al., 2014; MANAGI et al., 2009) and was chosen in this study because it is an essential component of economic growth and consequently increases international trade, economic activity and finally the consumption of energy (SADORSKY, 2012). Indeed, trade openness enables developing economies, which is the case of LAC countries, to import advanced technologies from developed countries. Therefore, the adoption of advanced technology lowers less energy use and produces output. Indeed, as trade openness is considered one of the potential factors that induce higher economic growth, and energy demand is expected to rise to respond to economic growth. For this reason, the variable Gross Domestic Production (Y) was used in this model.

Regarding the consumption of renewable (REC) and fossil (FOC) fuels, these variables were chosen in this investigation because the rapid development of renewable energy technologies will consequently decrease the consumption of non-renewable. The increase of production and consumption of fossil fuels in the region encourages the use of these variables. Moreover, the energy was used in this study because the import and export of goods and services need energy. Therefore, without a suitable energy supply, trade openness will be adversely impacted. That is, energy is an essential input in trade expansion, where suitable energy consumption is crucial for expanding trade via imports and exports.

The use of time-series from 1990 to 2014 is due to the availability of data until 2014 for the variable REC for all countries selected. The LAC countries were selected due to the rapid process of trade openness and consumption of fossil fuels and others. The availability of data is another motivation.

The variables FOC, Y, and REC were transformed into per capita values with the total population of each cross. The per capita value allows disparities to be controlled for in population growth over time and within countries (e.g., KOENGKAN et al., 2018b; KOENGKAN, 2018c; KOENGKAN, 2018d). Furthermore, this investigation used the GDP in constant 2010 US\$ instead of the constant Local Currency Unit (LCU). The initial estimations using constant 2010 US\$ presented slightly different results from when constant LCU was used. Indeed, these changes in results could be related to changes in the database source, as the old database from IEA was replaced by the World Bank database or by the exchange rates themselves. 
The variable of trade openness is the result of trade and economic liberalisation that is the integration of the national economy with the rest of the world. This integration has been one of the most important developments of the last century. Indeed, this process of integration, often called "globalisation"”, has materialised remarkable growth in trade between countries. Table 1 shows the summary statistics of variables.

Table 1 - Summary statistics of variables.

\begin{tabular}{cccccc}
\hline \multirow{2}{*}{ Variables } & \multicolumn{5}{c}{ Descriptive Statistics } \\
\cline { 2 - 6 } & Obs. & Mean & Std. Dev. & Min & Max \\
\hline LnFOC & 350 & 10.576 & 0.9261 & 7.4260 & 12.4303 \\
\hline LnY & 350 & 8.4631 & 0.6886 & 6.9659 & 9.5943 \\
\hline LnREC & 350 & 12.0473 & 4.8717 & 8.2764 & 30.9759 \\
\hline LnTR & 350 & 3.9433 & 0.4822 & 2.6212 & 5.1161 \\
\hline
\end{tabular}

Notes: Obs. denotes the number of observations; Std. Dev. Denotes the Standard Deviation; Min. and Max. Denote Minimum and Maximum, respectively. (Ln) denotes variables in natural logarithms.

Moreover, we should stress that they are already in their natural logarithms (see prefix “Ln").

\subsection{Methods}

For the realisation of this investigation, the PARDL model in the form of UECM will be used as our central model estimation, and a PNARDL model will be applied to check the robustness of results. The PARDL model in the form of UECM was developed by GRANGER (1981), and by ENGLE and GRANGER (1987), and later improved by JOHANSEN and JUSELIUS, (1980) who introduced cointegration techniques that allow the identification of a long-run relationship between non-stationary series and their parametrisation into an error correction model (UECM) (NKORO and UKO, 2016). This model allows decomposition of the total effects of variables into their short- and long-run components (KOENGKAN et al., 2019).

This model was employed in empirical researches that have several applications in the literature. Table 2 shows PARDL models applied in the literature. 


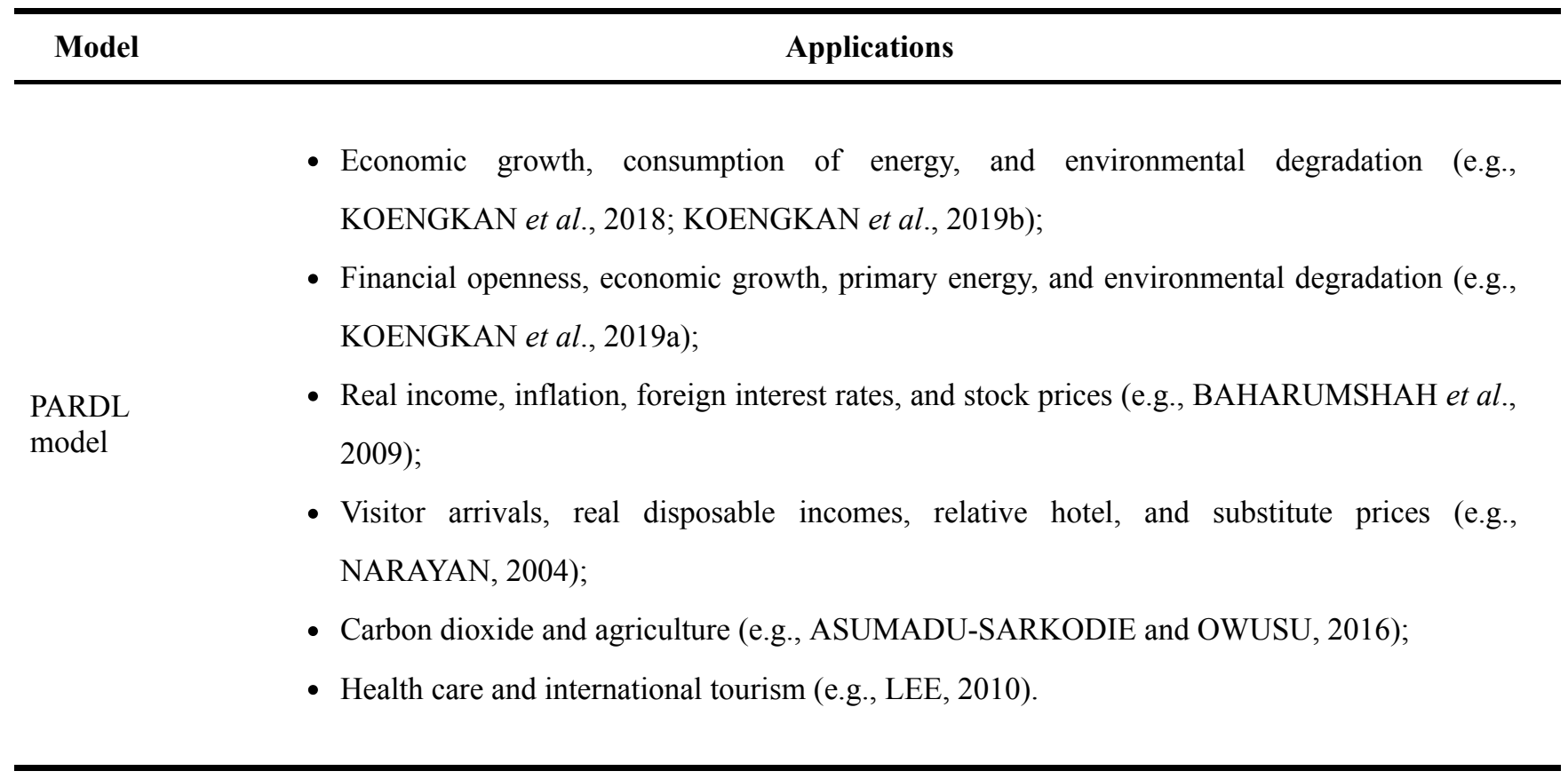

The general PARDL model in the form of UECM follows the specification of Equation (1):

$$
\begin{aligned}
& D L n F O C_{i t}=\alpha_{i t}+\beta_{1 i 1} D L n Y_{i t-1}+\gamma_{1 i 1}+D L n R E C_{i t-1}+\gamma_{3 i 1}+D L n T R_{i t-1}+ \\
& +\gamma_{4 i 1}+L_{n F O C}{ }_{i t-1}+\gamma_{1 i 2} L n Y_{i t-1}+\gamma_{1 i 3} L n R E C_{i t-1}+\gamma_{1 i 4} L n T R_{i t-1}+\varepsilon_{1 i t}
\end{aligned}
$$

where $\alpha_{i}$ represents the intercept, $\beta_{i k}$ and $\gamma_{i k}$, with $\mathrm{k}=1, \ldots, 3$, denote the estimated parameters and $\varepsilon_{i t}$ is the error term. The prefixes "Ln" and "DLn" denote natural logarithms and first-differences, respectively. Therefore, before the PARDL model estimation, it is mandatory to examine the characteristics of the variables, which includes the cross-section and time series, as well as to ascertain the presence of specificities which, if not considered, may produce inconsistent and incorrect results. To this end, the preliminary and specification tests will be performed before estimating the model of interest. The following tests are thus executed:

(i) Preliminary tests: (a) variance inflation factor (VIF) to check for the presence of multicollinearity among the variables; (b) cross-section dependence (CSD) test (PESARAN, 2004); (c) Pesaran's CADF test (PESARAN, 2003) to identify the presence of unit roots; (d) the Hausman test to identify heterogeneity, i.e., whether the panel has random effects (RE) or fixed effects (FE) and; (e) mean group (MG), fixed effects (FE), and pooled mean group (PMG) estimators.

(ii) Specification tests: (a) modified Wald test (GREENE, 2002) to check for the existence of groupwise heteroscedasticity; (b) Wooldridge test (WOOLDRIDGE, 2002) to check the presence of serial correlation; (c) Pesaran (2004) test for cross-sectional independence; and (d) Breusch and Pagan Lagrangian multiplier test (BREUSCH and PAGAN, 1980) for cross-sectional correlation in the fixed- 
effects model. The latter is used due to the large $\mathrm{T}$ (number of time-series observations) and the small $\mathrm{N}$ (number of cross-sectional observations) in the panel.

To appraise the robustness of results in the PARDL model, the PNARDL approach will be used. This model is an asymmetric extension of linear PARDL model in the form of UECM developed by GRANGER (1981) and by ENGLE and GRANGER (1987). Indeed, the PARDL model in the form of UECM does not consider the possibility that the positive and negative variations of the explanatory variables in the model have a different effect on the dependent variable (ROCHER, 2017). Regarding PNARDL, the same author explains that this model not only allows detection of the presence of asymmetric effects that independent variables may have on the dependent variable in the model, but it also allows testing for cointegration in a single equation.

Why was the PNARDL model used as a robustness check in this study? According to ROCHER (2017), the PNARDL model presents some advantages that are necessary to highlight, such as their flexibility regarding the order of integration of the variables involved, the possibility of testing for hidden cointegration, avoiding omission of any causality which is not visible in a conventional linear model, with better performance in small samples and being robust in the presence of endogeneity. According to SHIN et al. (2014), the PNARDL model is constructed around the following asymmetric long-run equilibrium relationship (see Equation 2):

$$
e_{t}=\delta^{+} x^{+}+\delta^{-} x^{-}+\mu_{i}
$$

where the equilibrium relationship between $e$ and $x$ is divided into positive $\left(\delta^{+} x^{+}\right)$and negative $\left(\delta^{-} x^{-}\right)$ effects, plus the error term $\left(\mu_{t}\right)$ means the possible deviations from the long-equilibrium. As shown in Equation (2), the effect of the variable $x$ can be decomposed into two parts, positive and negative (see Equation 3):

$$
x_{t}=x_{0}+x_{t}^{+}+x_{t}^{-}
$$

where $x_{0}$ represents the random initial value and $x_{t}^{+}+x_{t}^{-}$denote partial sum processes which accumulate positive and negative changes, respectively, and are defined as (see Equations 4 and 5):

$$
\begin{gathered}
x_{t}^{+}=\sum_{j=1}^{t} \Delta x_{j}^{+}=\sum_{j=1}^{t} \max \left(\Delta x_{j}, 0\right) \\
x_{t}^{-}=\sum_{j=1}^{t} \Delta x_{j}^{-}=\sum_{j=1}^{t} \min \left(\Delta x_{j}, 0\right)
\end{gathered}
$$

Then, the general PNARDL model in the form of UECM follows the specification of Equation (6): 


$$
\begin{aligned}
& D L n F O C_{i t}=\alpha_{i t}+\gamma_{1 i 1}+\theta_{1}^{+} D L n \gamma_{i t-1}^{+}+\theta_{1}^{-} D L n \gamma_{i t-1}^{-}+\gamma_{2 i 1}+\theta_{1}^{+} D L n R E C_{i t-1}^{+}+\theta_{1}^{-} D L n R E C_{i t-1}^{-}+\gamma_{3 i 1} \\
& +\theta_{1}^{+} D L n T R_{i t-1}^{+}+\theta_{1}^{-} D L n T R_{i t-1}^{-}+L N F O C_{i t-1}+\theta_{1}^{+} \gamma_{1 i 1} \operatorname{Ln} Y_{i t-1}^{+}+\theta_{1}^{-} \gamma_{1 i 1} \operatorname{Ln} Y_{i t-1}^{-} \\
& +\theta_{1}^{+} \gamma_{1 i 2} \operatorname{Ln} R E C_{i t-1}^{+}+\theta_{1}^{-} \gamma_{1 i 2} \ln R E C_{i t-1}^{+}+\theta_{1}^{+} \gamma_{1 i 3} \operatorname{LnTR}_{i t-1}^{+}+\theta_{1}^{-} \gamma_{1 i 4} \ln T R_{i t-1}^{-}+\varepsilon_{1 i t}
\end{aligned}
$$

where $\alpha_{i}$ represents the intercept, $\beta_{i k}$ and $\gamma_{i k}$, with $\mathrm{k}=1, \ldots, 3$, denote the estimated parameters, $D \operatorname{Ln} \gamma_{i t-1}^{+}, D L n \gamma_{i t-1}^{-}, D L n R E C_{i t-1}^{+}, D L n R E C_{i t-1}^{-}, D L n T R_{i t-1}^{+}, D L n T R_{i t-1}^{-}$, and $\operatorname{Ln} \gamma_{i t-1}^{+}$, $L n \gamma_{i t-1}^{-}, L n R E C_{i t-1}^{+}, \$ \$ \operatorname{LnREC}^{\wedge}\{-\}_{-}\{\mathrm{it}-1\}, L n T R_{i t-1}^{+}, L n T R_{i t-1}^{-}$are the partial sums of positive and negative changes of variables DLnY, DLnREC, DLnTR and LnY, LnREC, LnTR, respectively and $\varepsilon_{1 i t}$ is the error term. Moreover, it is worth remembering that were applied in the parsimonious model. That is, statistically insignificant variables were removed from the model (e.g., DLnY_POS, DLnY_NEG, DLnTR_POS, DLnTR_NEG, LnREC_POS, LnREC_NEG, LnTR_POS, and LnTR_NEG) in prior model's regressions (see Equation 6). Therefore, the parsimonious PNARDL model in the form of UECM follows the specification of Equation (7):

$$
\begin{aligned}
& D L n F O C_{i t}=\alpha_{i t}+\beta_{1 i 1} D L n \gamma_{i t}+\gamma_{1 i 1}+\theta_{1}^{+} D L n R E C_{i t-1}^{+}+\theta_{1}^{-} D L n R E C_{i t-1}^{-} \\
& +\gamma_{3 i 1}+D L n T R_{i t-1}+\gamma_{4 i 1}+L n F O C_{i t-1}+\theta_{1}^{+} \gamma_{1 i 2} L n \gamma_{i t-1}^{+} \\
& +\theta_{1}^{-} \gamma_{1 i 2} L n \gamma_{i t-1}^{-}+\gamma_{1 i 3} L n R E C_{i t-1}+\gamma_{1 i 4} L n T R_{i t-1}+\varepsilon_{1 i t}
\end{aligned}
$$

where $\alpha_{i t}$ represents the intercept, $\beta_{i k}$ and $\gamma_{i k}$, with $\mathrm{k}=1, \ldots, 3$, denote the estimated parameters, $D L n R E C_{i t-1}^{+}, D L n R E C_{i t-1}^{-}$, and $L n \gamma_{i t-1}^{+} \operatorname{Ln}^{\wedge}\{-\}_{-}\{$it-1\}\$ are the partial sums of positive and negative changes in variables DLnREC and LnY, respectively and $\varepsilon_{i t}$ is the error term. Additionally, the PNARDL model approach allows the use of a combination of variables I(0) and I(1). Nevertheless, it is essential to check the integration order of variables in previous steps as the PNARDL model is not valid for variables that are $\mathrm{I}(2)$.

This section shows the data/variables and methodologies and their preliminary and specification tests that will be used in our analysis. The next section will show the empirical results.

\section{Empirical Results}

As previously explained, this section will present the empirical results of preliminary and specification tests as well as the results of PARDL model estimation. The first step was the computation of VIF and CSD-tests. The first test informs the presence of multicollinearity, while the second shows cross-sectional dependence. The VIF test helps us to understand the degree of multicollinearity, which may be present in our model and which can lead to problems in estimation. The null hypothesis of CSD test is the presence of CSD in all variables. Therefore, in Table 5 we can see the results of VIF and CSD-tests, both in firstdifferences and natural logarithms. 
Table 3 - VIF and CSD tests.

\begin{tabular}{|c|c|c|c|c|c|c|}
\hline Variables & VIF & 1/VIF & \multicolumn{2}{|c|}{ CD-test } & Corr & Abs (corr) \\
\hline DLnFOC & \multicolumn{2}{|c|}{ n.a. } & 1.91 & $*$ & 0.041 & 0.221 \\
\hline DLnY & 1.02 & 0.9834 & 14.96 & $* * *$ & 0.320 & 0.323 \\
\hline DLnREC & 1.01 & 0.9857 & 2.05 & $* *$ & 0.044 & 0.200 \\
\hline DLnTR & 1.01 & 0.9934 & 12.37 & $* * *$ & 0.265 & 0.282 \\
\hline Mean VIF & \multicolumn{2}{|c|}{1.01} & & & & \\
\hline LnFOC & \multicolumn{2}{|c|}{ n.a. } & 32.96 & $* * *$ & 0.691 & 0.691 \\
\hline $\operatorname{LnY}$ & 1.34 & 0.7486 & 41.69 & $* * *$ & 0.874 & 0.874 \\
\hline LnREC & 1.27 & 0.7893 & 28.67 & $* * *$ & 0.601 & 0.610 \\
\hline LnTR & 1.10 & 0.9108 & 19.09 & $* * *$ & 0.400 & 0.502 \\
\hline Mean VIF & \multicolumn{2}{|c|}{1.23} & & & & \\
\hline
\end{tabular}

Notes: ***,**,* denote statistically significant at 1\%,5\%, and 10\% level; the Stata command estat vif and xtcd were used; (Ln and DLn) denote variables in natural logarithms and first-differences of logarithms respectively.

The information that is present in the previous table indicates that multicollinearity is not a concern in the estimation, given the low VIF and mean VIF values registered, which are lower than the usually accepted benchmarks of 10, in the case of the VIF values, and 6 in the case of the mean VIF values. Concerning the CSD-test, we see that the null hypothesis is rejected in all cases, leading us to the conclusion that there is a correlation between the series across countries.

In the presence of CSD, it is necessary to assess the order of integration of the variables. To this end, the Pesaran CADF test was computed. This test is robust in the presence of CSD, and we did not opt to use the first-generation test for the reason that it is inefficient in the presence of CSD. The null hypothesis of Pesaran's CADF is that all series are non-stationary I(0). The results of this test can be seen in Table 4 . 


\begin{tabular}{|c|c|c|c|c|c|}
\hline \multirow{4}{*}{$\begin{array}{l}\text { Variables } \\
\text { DLnFOC }\end{array}$} & \multicolumn{5}{|c|}{ Pesaran's CADF test (Zt-bar) } \\
\hline & \multicolumn{3}{|c|}{ Without trend } & \multirow{2}{*}{\multicolumn{2}{|c|}{$\begin{array}{c}\text { With trend } \\
\text { Zt-bar }\end{array}$}} \\
\hline & \multirow{2}{*}{$\frac{\text { Lags }}{1}$} & \multicolumn{2}{|c|}{ Zt-bar } & & \\
\hline & & -7.923 & $* * *$ & -5.558 & $* * *$ \\
\hline DLnY & 1 & -5.834 & $* * *$ & -4.964 & $* * *$ \\
\hline DLnREC & 1 & -8.770 & $* * *$ & -6.944 & $* * *$ \\
\hline DLnTR & 1 & -5.621 & $* * *$ & -3.851 & $* * *$ \\
\hline LnFOC & 1 & -2.360 & $* * *$ & -3.844 & $* * *$ \\
\hline LnY & 1 & -2.491 & $* * *$ & -0.338 & \\
\hline LnREC & 1 & -2.483 & $* * *$ & -3.434 & $* * *$ \\
\hline LnTR & 1 & -2.337 & $* * *$ & 0.080 & \\
\hline
\end{tabular}

Notes: $* * *$ denotes statistically significant at $1 \%$, level; the Stata command pescadf was used; The null for CADF test is: all series are nonstationary are I(1); the lag length (1) and trend were used in this test;(Ln and DLn) denote variables in natural logarithms and first-differences of logarithms respectively.

The results from the Pesaran CADF test show that none of the variables seems to be I(2), although they show that some of them may be in the borderline between the $\mathrm{I}(0)$ and $\mathrm{I}(1)$ orders of integration (i.e., in the first-differences with and without trend, and all variables in natural logarithms without trend, and also FOC and REC with trend seem to be stationary).

After the realisation of the unit root test, the next step is to assess the presence of individual effects in the model. To this end, the Hausman test, confronting random (RE) and fixed effects (FE), was performed. The null hypothesis of this test is that the difference in coefficients is not systematic, (i.e., random effects are the most suitable estimator). The Hausman test indicates that the null hypothesis should be rejected ( $\operatorname{chi}^{2}(7)=95.79$, statistically significant at $1 \%$ level) (see Table 5 in Appendix) and that a fixed-effects model is the most appropriate for this analysis.

To assess the presence of heterogeneity/homogeneity in the panel, the MG, PMG, and FE techniques were performed. The MG estimator that was developed by Pesaran and Smith (1995) calculates the average of coefficients of all individuals, with no restrictions regarding the homogeneity of short and long run. 
However, the PMG estimator created by PESARAN et al. (1999) permits for differences in error variances, short-run coefficients, speed of adjustment and intercepts (i.e., these parameters may be country-specific), but it imposes a homogeneity restriction on the long-run coefficients (i.e., they should be equal across countries).

Then, the PMG estimator can combine the "pooling" from the FE estimator with the "averaging" from the MG estimator. However, in the presence of panel homogeneity in the long-run, this estimator is more efficient than the MG estimator. Table 6 shows the outcomes for the three specifications (e.g., MG vs PMG; PMG vs FE; and MG vs FE).

Table 6 - Hausman test.

\begin{tabular}{ccc}
\hline MG vs PMG & PMG vs FE & MG vs FE \\
\hline $\mathrm{Chi}^{2}(7)=25.02 * * *$ & $\mathrm{Chi}^{2}(7)=75.71 * * *$ & $\mathrm{Chi}^{2}(7)=-107.99$ \\
\hline
\end{tabular}

Notes: ${ }^{* * *}$ denotes statistically significant at $1 \%$, level; Hausman results for $H_{0}$ : difference in coefficients not systematic; the Stata commands xtpmg, and Hausman (with the option alleqs) were used.

The results of Table 6 suggest that the panel is homogeneous and that the FE is the most appropriate estimator. Before model estimation, the following specification tests are performed: (a) the Modified Wald test; (b) the Wooldridge test; (c) Pesaran's test; and (d) the Breusch and Pagan Lagrangian multiplier test. Results are presented in Table 7.

Table 7 - Specification tests.

\begin{tabular}{|c|c|c|c|c|}
\hline \multirow{2}{*}{ Statistics } & Modified Wald test & Wooldridge test & $\begin{array}{l}\text { Pesaran's } \\
\text { test }\end{array}$ & $\begin{array}{c}\text { Breusch and Pagan Lagrangian multiplier } \\
\text { test }\end{array}$ \\
\hline & $\begin{array}{l}\operatorname{chi}^{2}(14)= \\
3147.01 * * *\end{array}$ & $\begin{array}{l}\mathrm{F}(1,13)= \\
85.298^{* * *}\end{array}$ & 0.125 & $\operatorname{chi}^{2}(91)=108.217$ \\
\hline
\end{tabular}

Notes: ${ }^{* *}$ denotes statistically significant at $1 \%$ level; $\mathrm{H} 0$ of Modified Wald test: sigma(i $)^{2}=$ sigma ${ }^{2}$ for all $\mathrm{i} ; H_{0}$ of Wooldridge test: no first-order autocorrelation; $H_{0}$ of Pesaran's test: residuals are not correlated; $H_{0}$ of Breusch and Pagan Lagrangian multiplier test: no dependence between the residuals.

The results of specification tests point to reject the null hypothesis of modified Wald and Wooldridge tests at the $1 \%$ level, indicating the presence of heteroscedasticity, and first-order autocorrelation. However, we cannot reject the null hypothesis of Pesaran's and Breusch and Pagan Lagrangian multiplier tests, indicating the non-presence of correlation and dependence in the residuals. 
Given the specification tests results, to deal with the presence of heteroscedasticity and first-order autocorrelation, we decided to use the Driscoll and Kraay (1998), estimator. This estimator was used because it produces standard errors which are robust to the phenomena that were found in the sample errors.

During the period of analysis, the LAC countries suffered several shocks that, if not taken into account, may produce inaccurate results. The dummy and shift-dummy variables added to the regression are the following: IDBRAZIL2009 (Brazil, year 2009); IDCOLOMBIA1997 (Colombia, year 1997); IDCOLOMBIA1999 (Colombia, year 1999); IDCOLOMBIA2009 (Colombia, year 2009); IDCOLOMBIA2011 (Colombia, year 2011); SDCOSTA_RICA1991_1994 (Costa Rica, years between 1991 to 1994); SDCOSTA_RICA2005_2006 (Costa Rica, years between 2005 to 2006); SDDOMINICAN_REPUBLIC1994_1995 (Dominican Republic, years between 1994 to 1995); IDDOMINICAN_REPUBLIC1998 (Dominican Republic, year 1998); SDECUADOR1993_1994 (Ecuador, years between 1993 to 1994); IDECUADOR1999 (Ecuador, year 1999); IDEL_SALVADOR1991 (El Salvador, year 1992); IDGUATEMALA1992 (Guatemala, year 1992); SDGUATEMALA1996_1997 (Guatemala, years between 1996 to 1997); IDGUATEMALA1998 (Guatemala, year 1998); and IDPANAMA1996 (Panama, year 1996).

The outcomes from the short-run impacts, the long-run elasticities, the speed of adjustment of the model with the FE, FE robust standard errors (FE Robust), and FE Driscoll and Kraay (FE D.-K.) estimators and shocks are displayed in Table 8. 
Table 8 - PARDL Model estimation controlling by shocks.

\begin{tabular}{|c|c|c|c|c|}
\hline \multirow{2}{*}{ Independent variables } & \multicolumn{4}{|c|}{ Dependent variable (DLnFOC) } \\
\hline & \multicolumn{2}{|c|}{ FE } & \multirow{2}{*}{$\frac{\text { FE Robust }}{*}$} & \multirow{2}{*}{$\frac{\text { FE D.-K. }}{* *}$} \\
\hline Constant & -1.0919 & $* *$ & & \\
\hline \multicolumn{5}{|c|}{ Shocks } \\
\hline IDBRAZIL 2009 & -0.4337 & $* * *$ & $* * *$ & $* * *$ \\
\hline IDCOLOMBIA1997 & 0.3866 & $* * *$ & $* * *$ & $* * *$ \\
\hline IDCOLOMBIA1999 & -0.3657 & $* * *$ & $* * *$ & $* * *$ \\
\hline IDCOLOMBIA2009 & 0.4424 & $* * *$ & $* * *$ & $* * *$ \\
\hline IDCOLOMBIA2011 & -0.4630 & $* * *$ & $* * *$ & $* * *$ \\
\hline SDCOSTA_RICA1991_1994 & -0.4374 & $* * *$ & $* * *$ & $* * *$ \\
\hline SDCOSTA_RICA2005_2006 & -0.3134 & $* * *$ & $* * *$ & $* * *$ \\
\hline SDDOMINICAN_REPUBLIC1994_1995 & -0.2523 & $* * *$ & $* * *$ & $* * *$ \\
\hline IDDOMINICAN_REPUBLIC1998 & 0.6432 & $* * *$ & $* * *$ & $* * *$ \\
\hline SDECUADOR1993_1994 & -0.4094 & $* * *$ & $* * *$ & $* * *$ \\
\hline IDECUADOR1999 & -0.4020 & $* * *$ & $* * *$ & $* * *$ \\
\hline IDEL_SALVADOR1991 & 0.8446 & $* * *$ & $* * *$ & $* * *$ \\
\hline IDGUATEMALA1992 & 0.9872 & $* * *$ & $* * *$ & $* * *$ \\
\hline SDGUATEMALA1996_1997 & -0.2763 & $* * *$ & $* * *$ & $* * *$ \\
\hline IDGUATEMALA1998 & 0.4393 & $* * *$ & $* * *$ & $* * *$ \\
\hline IDPANAMA1996 & -0.3851 & $* * *$ & $* * *$ & $* * *$ \\
\hline \multicolumn{5}{|c|}{ Short-run (impacts) } \\
\hline DLnY & 0.6255 & $* * *$ & $* * *$ & $* * *$ \\
\hline DLnREC & -0.4731 & $* * *$ & $* * *$ & $* * *$ \\
\hline DLnTR & 0.2235 & $* * *$ & $* * *$ & $* * *$ \\
\hline \multicolumn{5}{|c|}{ Long-run (elasticities) } \\
\hline $\operatorname{LnY}(-1)$ & 2.0488 & $* * *$ & $* * *$ & $* * *$ \\
\hline $\operatorname{LnREC}(-1)$ & -0.3508 & $* *$ & $* *$ & $* *$ \\
\hline $\operatorname{LnTR}(-1)$ & 0.5912 & $* * *$ & $*$ & $* * *$ \\
\hline \multicolumn{5}{|c|}{ Speed of adjustment } \\
\hline ECM & -0.2374 & $* * *$ & $* * *$ & $* * *$ \\
\hline
\end{tabular}

Notes: $* * * * *, *$ denote statistically significant at $1 \%, 5 \%$, and $10 \%$ level, respectively; the ECM denotes the coefficient of the variable LnFOC, lagged once; (Ln and DLn) denote variables in natural logarithms and first-differences of logarithms respectively.

Although we present the results of the model with these three estimators, we should clarify that we will base our inference on the FE Driscoll and Kraay estimator, given that it is the most robust. The inclusion of the other two estimators (i.e., FE and FE robust) was mainly linked with the possibility of seeing the differences between them, i.e., seeing the changes in the results when we control/do not control for the phenomena which were detected in the specification tests. 
The results of PARDL model estimation indicated that, in the impact of variable Y, and elasticity of TR are statistically significant at the $1 \%$ levels, and thus both contribute to the increasing of FOC in the LAC region. However, the impact and elasticity of REC is statistically significant at $1 \%$ and $5 \%$ levels and thus contribute to the decrease in consumption of non-renewable energy in the region. Regarding the ECM term, it is negative and statistically significant at the $1 \%$ level. In the next section, the robustness check will be shown with the realisation of PNARDL model. This verification will be made to test if the coefficients generated by PARDL are consistent with the change in methodology approach.

\section{Robustness check}

In this section, we assess the robustness of our results using a PNARDL approach. This model, as previously explained in subsection 2.2, is an asymmetric extension of a linear PARDL model in the form of UECM. This model also allows detection of the possible asymmetric nonlinearity and short- and longrun relationship. Moreover, it is worth remembering that the parsimonious model was estimated. That is, the insignificant variables (e.g., DLnY_POS, DLnY_NEG, DLnTR_POS, DLnTR_NEG, LnREC_POS, LnREC_NEG, LnTR_POS, and LnTR_NEG) from previous regressions of the general model were removed (see Equation 7).

The preliminary tests that check the characteristics of variables point to the presence of lowmulticollinearity, cross-sectional dependence, unit roots in the first-differences with and without trend, and all variables in the natural logarithms without a trend. Additionally, the variables FOC and REC with the trend are stationary, while the variables $\mathrm{Y}$ and TR in natural logarithms and with the trend are nonstationary, the fixed effects in the model. These results can be seen in Tables 1, 2, 3, and 4 in Appendix . Therefore, the preliminary tests in PARDL and PNARDL are the same.

The results of the heterogeneity/homogeneity test also indicate that the FE technique is the most appropriate for the fixed effects homogeneous model (see Table 8 in Appendix), and the results of specification tests indicate that the null hypothesis of Modified Wald and Wooldridge tests are rejected at $1 \%$ levels, indicating the presence of heteroscedasticity and first-order autocorrelation. Additionally, the null hypothesis of Pesaran's test cannot be rejected, indicating the non-presence of correlation. Regarding the Breusch and Pagan Lagrangian multiplier test, it could not be computed because the correlation matrix of residuals was singular. This situation occurs because the number of crosses under study is less than the number of years (see Table 9 in Appendix). Estimates for PNARDL model coefficients are shown in Table 10. 
Table 10 - PNARDL Model estimation controlling by shocks from robustness check.

\begin{tabular}{|c|c|c|c|c|}
\hline \multirow{3}{*}{$\begin{array}{c}\text { Independent variables } \\
\text { Constant }\end{array}$} & \multicolumn{4}{|c|}{ Dependent variable (DLnFOC) } \\
\hline & \multicolumn{2}{|c|}{ FE } & \multirow{2}{*}{$\frac{\text { FE Robust }}{* * *}$} & \multirow{2}{*}{$\frac{\text { FE D.-K. }}{* * *}$} \\
\hline & 0.9515 & $* * *$ & & \\
\hline \multicolumn{5}{|c|}{ Shocks } \\
\hline IDBRAZIL 2009 & -0.4284 & $* * *$ & $* * *$ & $* * *$ \\
\hline IDCOLOMBIA1997 & 0.3700 & $* * *$ & $* * *$ & $* * *$ \\
\hline IDCOLOMBIA1999 & -0.3601 & $* * *$ & $* * *$ & $* * *$ \\
\hline IDCOLOMBIA2009 & 0.4347 & $* * *$ & $* * *$ & $* * *$ \\
\hline IDCOLOMBIA2011 & -0.4796 & $* * *$ & $* * *$ & $* * *$ \\
\hline SDCOSTA_RICA1991_1994 & -0.4323 & $* * *$ & $* * *$ & $* * *$ \\
\hline SDCOSTA_RICA2005_2006 & -0.3100 & $* * *$ & $* * *$ & $* * *$ \\
\hline SDDOMINICAN_REPUBLIC1994_1995 & -0.2816 & $* * *$ & $* * *$ & $* * *$ \\
\hline IDDOMINICAN_REPUBLIC1998 & 0.6029 & $* * *$ & $* * *$ & $* * *$ \\
\hline SDECUADOR1993_1994 & -0.4125 & $* * *$ & $* * *$ & $* * *$ \\
\hline IDECUADOR1999 & -0.3966 & $* * *$ & $* * *$ & $* * *$ \\
\hline IDEL_SALVADOR1991 & 0.8157 & $* * *$ & $* * *$ & $* * *$ \\
\hline IDGUATEMALA1992 & 0.9655 & $* * *$ & $* * *$ & $* * *$ \\
\hline SDGUATEMALA1996_1997 & -0.2789 & $* * *$ & $* * *$ & $* * *$ \\
\hline IDGUATEMALA1998 & 0.4400 & $* * *$ & $* * *$ & $* * *$ \\
\hline IDPANAMA1996 & -0.3813 & $* * *$ & $* * *$ & $* * *$ \\
\hline \multicolumn{5}{|c|}{ Short-run (impacts) } \\
\hline DLnY & 0.6649 & $* * *$ & $* * *$ & $* * *$ \\
\hline DLnREC_POS & -0.3755 & $* * *$ & $* *$ & $* * *$ \\
\hline DLnREC_NEG & -0.6219 & $* * *$ & $* * *$ & $* * *$ \\
\hline DLnTR & 0.2364 & $* * *$ & $* * *$ & $* * *$ \\
\hline \multicolumn{5}{|c|}{ Long-run (elasticities) } \\
\hline LnY_POS (-1) & 0.5148 & $* * *$ & $* * *$ & $* * *$ \\
\hline LnY_NEG (-1) & 0.5490 & $* * *$ & $* * *$ & $* * *$ \\
\hline $\operatorname{LnREC~(-1)~}$ & -0.0822 & $* *$ & $* *$ & $* *$ \\
\hline $\operatorname{LnTR}(-1)$ & 0.1427 & $* * *$ & $* *$ & $* * *$ \\
\hline \multicolumn{5}{|c|}{ Speed of adjustment } \\
\hline ECM & -0.2456 & $* * *$ & $* * *$ & $* * *$ \\
\hline \multicolumn{5}{|c|}{ Wald's parameter equality test } \\
\hline \multirow{2}{*}{ Variables } & \multicolumn{2}{|c|}{ DLnREC } & \multicolumn{2}{|c|}{$\operatorname{LnY}$} \\
\hline & \multicolumn{2}{|c|}{$F(1,13)=2.31$} & \multicolumn{2}{|c|}{$F(1,13)=0.28$} \\
\hline
\end{tabular}

Notes: ***,** denote statistically significant at $1 \%$, and $5 \%$ level, respectively; the ECM denotes the coefficient of the variable LnFOC, lagged once; (Ln and DLn) denote variables in natural logarithms and first-differences of logarithms respectively; the H0 of Wald's parameter equality test is the existence of symmetry. 
The PNARDL indicates that the impact of $\mathrm{Y}$ and the positive and negative asymmetry of their elasticity, and the impact of TR and its elasticity contribute to an increase in the consumption of nonrenewable energy. However, the asymmetry of the impact of REC and their elasticity decrease the consumption of non-renewable energy.

The results of PNARDL indicate that the impact of REC and the elasticity of $\mathrm{Y}$ are asymmetric nonlinearity. Indeed, only these two variables, i.e., REC and Y, were added in this estimation due to their statistical significance in the model regression. Furthermore, the coefficients of shocks and variables remain statistically significant at the $1 \%$ and $5 \%$ levels, and the ECM term remains negative and statistically significant at the $1 \%$ level. The next section will present a more thorough discussion of the results from the model estimations.

\section{Discussions}

This investigation approaches the effect of trade openness on non-renewable energy sources in fourteen countries from the LAC region. The results of the preliminary tests indicate the presence of low multicollinearity and CSD in the data (see Table 1). Indeed, the presence of CSD in all variables in the first-difference and natural logarithms is mainly the result of the interdependency that exists across the economies in the countries from our sample.

The results of Pesaran's CADF test indicate that the variables in the first-differences with and without trend, and all variables in the natural logarithms without trend, and also the variables FOC and REC with trend are stationary, while the variables $\mathrm{Y}$ and TR in natural logarithms and with trend are non-stationary (see Table 2).

This indication reinforces the fact that the PARDL model is the best approach for this analysis and the reason that, as was previously explained, it allows for the incorporation of variables that are $\mathrm{I}(0)$ and $\mathrm{I}(1)$ in the same estimation. Indeed, due to stationarity in the variables in first-differences and natural logarithms, it is not necessary for the realisation of the cointegration tests. The Hausman test indicates that the null hypothesis should be rejected $\left(\mathrm{chi}^{2}(7)=95.79\right)$, statistically significant at $1 \%$ levels) (see in Table 4 in Appendix) and that a fixed-effects model is the most appropriate for this analysis, and the heterogeneity/homogeneity test also indicates that the FE technique is the most appropriate for the fixed effects homogeneous model (see Table 5). 
The specification tests indicated the presence of heteroscedasticity and first-order autocorrelation, as well as the non-presence of correlation and dependence in the residuals (see Table 6). Therefore, the FE, FE robust standard errors (FE Robust), and FE Driscoll and Kraay (FE D.-K.) estimators were used in this study.

Moreover, the dummy and shift-dummy variables were introduced to account for shocks (peaks and breaks of significant magnitude) which occurred in some countries in the LAC region (see subsection 3).

The PARDL estimated general model (including the dummies and shift-dummies) suggests that the impact and elasticity of $Y$ have a positive impact on the consumption of non-renewable energy of 0.6255 and 2.0488, respectively. The impact and elasticity of the variable TR also have a positive impact on the consumption of non-renewable energy, where trade openness has an impact of 0.2235 and 0.5912 , respectively.

However, as expected, the impact and elasticity of REC have a negative impact of -0.4731 and -0.3508 , respectively. That is, the consumption of energy from renewable sources reduces the consumption of fossil fuels. Regarding the ECM term, it is negative and statistically significant at the $1 \%$ level, and also the statistical significance at the $1 \%$ level of the dummy and shift-dummy variables support the decision to include them in the model. Based on this evidence, we can approach the following questions: (i) Are the empirical finds of this investigation in agreement with the literature? (ii) What are the possible explanations for the identified impacts? (iii) Is the process of globalisation by trade openness of LAC countries able to help to decrease the consumption of fossil fuels? (iv) Do the empirical results of this investigation confirm one or more of the research hypotheses?

The positive impact of economic growth on consumption of energy from non-renewable sources is in keeping with several authors that studied the relationship in the Latin America region (e.g., KOENGKAN et al., 2019b; KOENGKAN, 2018c; KOENGKAN, 2018d; KOENGKAN, 2017; RODRÍGUEZCABALLERO and VENTOSA-SANTAULÀRIA, 2017; PABLO-ROMERO AND JÉSUS, 2016; PASTÉN et al., 2015).

Therefore, the positive impact of economic growth on the consumption of non-renewable energy in the LAC countries is due to the region being very sensitive to changes to change in economic activity, where a rapid economic growth exerts a positive effect on the consumption of energy from non-renewable energy sources (PABLO-ROMERO and JÉSUS, 2016). 
This idea is accepted by several authors, such as KOENGKAN et al. (2019b), and KOENGKAN (2018c), according to whom the Latin America region has experienced strong economic growth, and they have demanded an even more significant increase in energy use. However, KOENGKAN (2018d) investigated the Andean community countries in the South America region and had a different vision about this positive impact of economic growth on the consumption of non-renewable energy. According to it, the LAC countries are dependent on the consumption of energy for growth, where an increase of $1 \%$ in the energy demand consequently increases economic activity by $0.5 \%$. This is in line with LIDDLE and SADORSKY (2017) who defend that, in countries where economic activity is heavily dependent on the burning of fossil fuels (as a consequence of technological, political, and socio-economic factors), the transition to renewable energy sources is very difficult.

Other authors such as FUINHAS et al. (2017) who studied the effect of renewable energy policies on environmental degradation also confirms that the countries from the Latin America region have a high economic dependence on fossil fuel energy sources, due to the fact that some countries in the region are major energy producers (e.g., Argentina, Brazil, Colombia; Mexico, Venezuela (RB), and Ecuador), and others are significant importers (e.g., Brazil, Chile, Dominican Republic, Uruguay, Paraguay).

OMRI et al. (2014) have other explanation for this positive impact. According to these authors, economic capitalisation, the development of infrastructure and trade openness in LAC countries are responsible for this positive impact, where these factors have a positive effect on investment, economic activity and consequently on the consumption of energy.

The possible explanation for the negative impact of consumption of renewable energy on nonrenewable in the LAC countries is due to the vast abundance of renewable energy sources i.e., solar, photovoltaic, wind, hydropower, geothermal, and waste, in these countries which stimulate investment in renewable energy technology and consequently decrease the consumption of non-renewable (FUINHAS et al., 2017).

According to KOENGKAN (2018c), this negative impact of renewable energy consumption on fossil fuel consumption demonstrates that the renewable energy policies in the LAC countries are effective and can encourage the development of renewable energy technologies and the consumption of energy from this kind of source. The author also claims that this results in evidence that renewable energy technologies used in these countries are effective in reducing the consumption of non-renewables and environmental degradation. 
However, this capacity of renewable energy to reduce the consumption of fossil fuels could be related to the process of globalisation via financial openness that increases capital stock and consequently reduces the cost of external financing, encouraging investment in renewable energy technologies (KOENGKAN et al., 2019f).

Thus, the reduction of fossil fuel consumption by renewable energy found in this analysis confirms the process of "energy transition" in LAC countries. According to HAUFF et al. (2014), the term "energy transition" indicates a growing trend of the share of renewable energy sources to reduce the consumption of fossil fuels. Indeed, this term gives a clear objective of reducing environmental degradation.

The impact of the reduction of renewable energy consumption on the consumption of non-renewable energy is modest. According to YORK (2012), this low impact of renewable energy on non-renewable energy is related to the expansion of the production of renewable energy that will suppress that of nonrenewable energy. For this author, the failure of renewable energy sources to displace fossil fuels is probably in part related to the established energy system as the result of lock-in to using renewable energy sources as the base of the energy mix. This could be related to the prevalence of infrastructures and economic policies that support the fossil fuel industry. Moreover, this low capacity for renewable energy sources to decrease the consumption of fossil fuels could be linked to periods of low production caused by drought or climate change. In such cases, in order to attend to the energy demand, thermoelectrics powered by fossil fuels are activated. According to KOENGKAN et al., (2019g), the renewable and fossil fuel energy sources substitute each other in the energy matrix in the Latin American countries.

Finally, the positive impact of trade openness on the consumption of non-renewable energy is in line with some authors that investigated this relationship (e.g., KOENGKAN, 2018d; SEBRI and BENSALHA, 2014; HOUSSAIN, 2011; COLE, 2006; JENA and GROTE, 2008). According to KOENGKAN (2018d) and HOUSSAIN (2011), trade openness encourages an expansion of industrialisation and rapid economic development and consequently increases the consumption of energy from non-renewable energy sources. COLE (2006) has the same idea, pointing out that trade openness increases the per capita income by $1 \%$ approximately, and consequently increases the energy demand in the interval between $0.05 \%$ and $0.3 \%$, approximately. Moreover, this positive impact of trade openness can be related to the nondiversification of exports and imports that restrict the acquisition of new products with advanced technologies and high energy efficiency. This was mentioned by Gozgor and CAN (2017), who pointed out that the diversification of exports facilitates the acquisition and spread of new technologies, thus contributing to enhance a country's level of knowledge. 
However, SEBRI and BEN-SALHA (2014) have a different opinion about this impact. According to these authors, trade openness brings more investment to the energy sector, principally to non-renewable energy due to the abundance of non-renewable energy sources in these countries. This investment consequently stimulates the consumption of energy. Other authors, for example, JENA and GROTE (2008), point that industrialisation processes by scale effect, technique effect, and comparative advantages effect brought about by trade liberalisation exert a positive impact on economic growth and consequently in the consumption of energy. That is, this result confirms that the trade openness exerts a positive effect on the consumption of energy, as trade liberalisation brings more industrialisation and investment that affect economic growth and consequently increase energy demand.

Regarding the results of PNARDL, they confirm the same results from the PARDL model. The PNARDL indicates that the impact of REC and the elasticity of $\mathrm{Y}$ have asymmetric nonlinearity. Additionally, the positive and negative asymmetry of the variables in first-differences of REC and natural logarithms of $\mathrm{Y}$ are not asymmetrically different. The Wald's parameter equality test (positive and negative asymmetric) clearly supports this evidence.These results indicate that the model that we formulated is robust to changes in methodologic approach (see Table 10).

This section discussed possible explanations for the positive impact of trade openness and economic growth on the consumption of fossil fuels, and for the negative impact of renewable energy consumption. The next section will focus on the policy implications of the empirical anaylsis' results.

\section{Conclusions and policy implications}

The main aim of this investigation is to analyse the impact of the trade openness on the consumption of energy from non-renewable sources. Fourteen LAC countries were selected in a period 1990 to 2014. This investigation opted to use PARDL as the methodology in the form of a UECM and to check the robustness of the main model PNARDL was used.

The preliminary tests of this study indicated that the variables used have characteristics such as lowmulticollinearity, cross-sectional dependence in the variables in logarithms and first-differences, and in almost all cases, I(0)/I(1) for all variables, and also the presence of fixed effects. Additionally, the specification tests indicated the presence of heteroscedasticity and first-order autocorrelation, as well as the non-presence of correlation and dependence in the residuals. The results of these tests are essential to identify the characteristics of countries that are under study as well as possible methodologies that will be applied. 
The results of the PARDL model indicated that in the short and long run, the impact and the elasticity of variable economic growth and trade openness are statistically significant at the $1 \%$ level, and thus both contribute to the consumption of energy from non-renewable sources. Nevertheless, the impact and the elasticity of the variable consumption of renewable energy is statistically significant at the $1 \%$ and $5 \%$ levels and thus contribute to a decrease in the consumption of fossil fuels in the LAC region. The PNARDL that verifies the robustness of the PARDL model indicates the same results. Additionally, PNARDL also points towards the impact of the variable renewable energy consumption and the elasticity of economic growth having asymmetric nonlinearity. That is, the results of PARDL and PNARDL confirmed that trade openness increases the consumption of non-renewable energy.

Therefore, the positive impact of trade openness on the consumption of fossil fuels indicates that the process of globalisation by trade liberalisation in LAC countries is not sufficient to attract more investment, capable of encouraging R\&D in energy efficiency technologies, and in equipment that reduces the consumption of energy from non-renewable energy sources by households and firms.

In order to reverse the increase in consumption of fossil fuels, LAC countries need to create mechanisms to diversify the nature of their exports and imports, aiming at the acquisition and development of new products, with higher technological intensity, capable of enhancing the production of renewable energy and reducing the consumption of non-renewables. As Gozgor and Can (2017) defended, diversification of exports and imports encourages the acquisition of new technologies. Also Shahbaz et al. (2014) considered that trade openness is a source for the transfer of advanced technologies, for example, energy-efficient technology from developed countries to developing ones. Thus, the LAC countries should import more energy-efficient technologies from developed economies in order to reduce their energy consumption. However, this will not be possible if LAC countries develop mechanisms, such as new tariff and non-tariff barriers on products and technologies that improve energy efficiency. Indeed, energyefficiency product standards and labelling are policy mechanisms that impact the consumption of fossil fuels. This mechanism according to Ghani (2012), is a valuable policy tool to encourage the improvement of energy efficiency and the energy-efficient product standards during the trade liberalisation process.

Additionally, the increase of energy efficiency (in buildings, systems related to the infrastructure, transport, and in sections of production) is a priority of the LAC governments that can not be undermined. Other mechanisms should be implemented in the LAC countries due to their characteristics, such as the decentralisation of energy production that improves the performance of the system, and the design of more 
public policies aimed at motivating the everyday use of zero-emissions systems and technologies (e.g., renewable energy technologies).

Moreover, this investigation makes a significant contribution to the literature for several reasons. First, it sheds light on how economic growth and trade openness increases the consumption of fossil fuels in the LAC. Second, it shows how the consumption of renewable energy decreases the consumption of fossil fuels. Third, the empirical results of this investigation have critical consequences for governments and policymakers with respect to the current model of trade openness, where LAC countries do not take advantage of liberalisation to bring more investment that encourages the R\&D in energy efficiency technologies, and equipment that reduces the consumption of energy. Moreover, this investigation is an opportunity for policymakers and governments to reflect on the current mechanisms that are used in trade liberalisation and which are not beneficial for the environment. Fourth, this study can open a new field of research about the effects of trade openness on technological progress in the energy sector, in order to identify whether the process of trade liberalisation brings energy efficiency and encourages the process of the energy transition.

\section{Acknowledgements}

This study was funded by National Funds of the FCT - Portuguese Foundation for Science and Technology within the project UID/ECO/04007/2019, and NECE - Research Unit in Business Science and Economics, sponsored by the FCT and Higher Education, project UIDB/05037/2020. NECE, R\&D unit funded by the Portuguese Science and Technology Foundation and Ministry of Higher Education Science and Technology. Fundação para a Ciência e a Tecnologia.

\section{References}

AGOSIN M.R., FFRENCH-DAVIS R., Trade liberalization in Latin America. CEPAL Review, v.50, n.124, p.42-62, 1993. URL: https://repositorio.cepal.org/bitream/handle/ 11362/10440/1/50041062I_en.pdf.

ASUMADU-SARKODIE S., OWUSU P.A., The relationship between carbon dioxide and agriculture in Ghana: a comparison of VECM and ARDL model. Environmental Science and Pollution Research, v.23, n.11, p.10968-10982, 2016. doi: https://doi.org/10.1007/s11356-016-6252-x.

BAHARUMSHAH A.Z., MOHD S.H., MASHI A.M.M., (The stability of money demand in China: Evidence from the ARDL model. Economic Systems, v.33, n.2, p.231-244, 2009.doi: https://doi.org/10.1016/j.ecosys.2009.06.001.

BREUSCH T.S, PAGAN A.R., The Lagrange multiplier test and its applications to model specification in econometrics. The Review of Economic Studies, v.47, n.1.,p. 239-253,1980. URL: https://www.jstor.org/stable/2297111. 
COE D.T, HELPMAN E., HOFFMAISTER A.W., North-south R\&D spillovers. Economic Journal, v.107, .440, p.134149,1997.URL: https://www.jstor.org/stable/2235275.

COLE M.A., Does trade liberalization increase national energy use?. Economics Letters,v.92, n.1, p.108-112, 2006. doi: https://doi.org/10.1016/j.econlet.2006.01.018.

DRISCOLL J. C., KRAAY A. C., Consistent Covariance Matrix Estimation with Spatially Dependent Panel Data. Review of Economics and Statistics, v. 80, n.4, p.549-560,1998. doi: https://doi.org/10.1162/003465398557825.

ENGLE R.F, GRANGER C.W.J., Cointegration and Error Correction: Representation, Estimation and Testing. Econometrica, v.55, p.251-276,1987. URL: https://www.jstor.org/stable/1913236.

FUINHAS J.A., MARQUES A.C., KOENGKAN M., Are renewable energy policies upsetting carbon dioxide emissions? The case of Latin America countries. Environmental Science and Pollution Research, v.24, n.17, p.15044-15054,2017. doi: https://link.springer.com/article/10.1007/s11356-017-9109-z.

GHANI G.M., Does trade liberalization effect energy consumption?. Energy Policy, v.43, p.285-290,2012.. doi: https://doi.org/10.1016/j.enpol.2012.01.005.

GOZGOR G., CAN M. Causal linkages among the product diversification of exports, economic globalization and economic growth. Review of Development Economics v.21, n3., p.888-908,2017.doi: https://doi.org/10.1111/rode.12301.

GRANGER C.W.J., Some Properties of Time Series Data and Their Use in Econometric Model Specification. Journal of Econometrics, v.28, p.121-130,1981. doi: https://doi.org/10.1016/0304-4076(81)90079-8.

GREENE W., Econometric Analysis. Saddle River, New Jersey: Prentice-Hall,2002.

HAUFF J., BODE A., NEUMANN D., HASLAUER F., Global Energy Transitions a comparative analysis of key countries and implications for the international energy debate. World energy council, p.1-30,201. URL: https://www.extractiveshub.org/resource/view/id/13542.

HENRY M., KNELLER R., MILNER C., Trade, technology transfer and national efficiency in developing countries. European Economic Review, v.53, n.2., p.237-254,2009. doi:https://doi.org/10.1016/j.euroecorev.2008.05.001.

HOUSSAIN M.D.S., Panel estimation for CO2 emissions, energy consumption, economic growth, trade openness and urbanization of newly industrialized countries. Energy Policy, v.39, n.11, p.6991-6999,2011. doi: https://doi.org/10.1016/j.enpol.2011.07.042.

IEA (International Energy Agency). Oil market report. p1-26,2018. URL: https://www.iea.org/oilmarketreport/.

IRENA (International Renewable Energy Agency). Renewable Energy Market Analysis: Latin America. IRENA,p.1260,2016. ISBN:978-92-95111-50-9. URL: https://www.irena.org/publications/2016/Nov/Renewable-Energy-MarketAnalysis-Latin-America.

JENA P.R., GROTE U., Growth-trade-environment nexus in India. Proceedings of the German development economics conference, Zurich, v.18,p.1-16,2008.URL: https://www.econstor.eu/bitstream/10419/39895/1/AEL_2008_18_jena.pdf. 
JOHANSEN S., JUSELIUS K., Maximum Likelihood Estimation and Inference on Cointegration with Applications to the Demand for Money. Oxford Bulletin of Economics and Statistics,v.52, n.2, p.169-210,1990. doi: https://doi.org/10.1111/j.1468-0084.1990.mp52002003.x.

JURADO M., Latin America’s Oil Trade Flow. Energia16, 2018.URL: https://www.energia16.com/latin-americas-oil-tradeflow/?lang=en.

KOENGKAN M., The decline of environmental degradation by renewable energy consumption in the MERCOSUR countries: an approach with ARDL modelling. Environment Systems and Decisions, v.38, n..3.,p.415-425, 2018c. doi: https://doi.org/10.1007/s10669-018-9671-z.

KOENGKAN M., The positive impact of trade openness on the consumption of energy: Fresh evidence from Andean community countries. Energy, v.158, n.1, p.936-943, 2018d. doi: https://doi.org/10.1016/j.energy.2018.06.091.

KOENGKAN M., FUINHAS J.A., MARQUES A.C., Does financial openness increase environmental degradation? Fresh evidence from MERCOSUR countries. Environmental Science and Pollution Research, v.25, n.30,p. 30508-30516, 2018b. doi: https://doi.org/10.1007/s11356-018-3057-0.

KOENGKAN M., FUINHAS J.A., MARQUES A.C., The role of financial openness and China's income on fossil fuels consumption: fresh evidence from Latin American countries. GeoJournal, p.1-15, 2019b. doi: https://doi.org/10.1007/s10708-019-09969-1.

KOENGKAN M., FUINHAS J.A., MARQUES A.C., The relationship between financial openness, renewable and nonrenewable energy consumption, $\mathrm{CO} 2$ emissions, and economic growth in the Latin American countries: an approach with a panel vector auto regression model. The Extended Energy-Growth Nexus:Theory and Empirical Applications, pp. 199-229, 2019g.doi: https://doi.org/10.1016/B978-0-12-815719-0.00007-3.

KOENGKAN M., FUINHAS J.A., VIEIRA I., Effects of financial openness on renewable energy investments expansion in Latin American countries. Journal of Sustainable Finance \& Investment, p.1-29, 2019f.doi: : https://doi.org/10.1080/20430795.2019.1665379.

KOENGKAN M., SANTIAGO R., FUINHAS J.A., MARQUES A.C., Does financial openness cause the intensification of environmental degradation? New evidence from Latin American and Caribbean countries. Environmental Economics and Policy Studies, p.1-26, 2019a. doi: https://doi.org/10.1007/s10018-019-00240-y.

KOENGKAN M., SANTIAGO, R., FUINHAS J.A., The impact of public capital stock on energy consumption: Empirical evidence from Latin America and the Caribbean region. International Economics, p.1-23, 2019e.doi: https://doi.org/10.1016/j.inteco.2019.09.001.

KOENGKAN M., SOUSA F.J.F., The impact of wind power consumption on the labour market-a study of ten Europe union member countries. Revista Brasileira de Energias Renováveis, v.8, n.1., p.76-103,2019d. doi: http://dx.doi.org/10.5380/rber.v8i1.53821.

KOENGKAN M.; LOSEKANN L.D., FUINHAS J.A., The relationship between economic growth, consumption of energy, and environmental degradation: renewed evidence from Andean community nations. Environment Systems and Decisions, p.1-13,2018a. doi: 10.1007/s10669-018-9698-1. 
KRAFT J., KRAFT A., On the relationship between energy and GNP. Journal of Energy Development, v.3, n.2, p.401403, 1978.URL: https://www.jstor.org/stable/pdf/24806805.pdf?seq=1\#page_scan_tab_contents.

LEE C.G.,Health care and tourism: Evidence from Singapore. Tourism Management, v.31, 4., p.486-488,2010. doi: https://doi.org/10.1016/j.tourman.2009.05.002.

LIDDLE B., SADORSKY P., How much does increasing non-fossil fuels in electricity generation reduce carbon dioxide emissions?. Applied Energy, v.197,p.212-221,2017.doi: https://doi.org/10.1016/j.apenergy.2017.04.025.

MANAGI S., HIBIKI A., TSURUMI T., Does trade openness improve environmental quality?. Journal of Environmental Economics and Management, v.58, n.3, p.346-363,2009. doi: https://doi.org/10.1016/j.jeem.2009.04.008.

NARAYAN P.K., Fiji's Tourism Demand: The ARDL Approach to Cointegration. Tourism Economics, v.10, n.2.,p.193206,2004. doi: https://doi.org/10.5367/000000004323142425.

NASREEN S., ANWAR S., The causal relationship between trade openness, economic growth and energy consumption: A panel data analysis of Asian countries. Energy Policy, v.69, p.82-91,2014. doi: https://doi.org/10.1016/j.enpol.2014.02.009.

NKORO E., UKO A.K., (2016). Autoregressive Distributed Lag (ARDL) cointegration technique: application and interpretation. Journal of Statistical and Econometric Methods, v.5, n.4., p.63-91,2016. ISSN: 1792-6602.URL: http://www.scienpress.com/Upload/JSEM\%2fVol\%205_4_3.pdf.

OMRI A., NGUYEN D. K., RAULT C., Causal interactions between CO2 emissions, FDI, and economic growth: Evidence from dynamic simultaneous-equation models. Economic Modelling, v.42, p.382-389,2014. doi: https://doi.org/10.1016/j.econmod.2014.07.026.

PABLO-ROMERO M.D., JÉSUS J.D., Economic growth and energy consumption: The Energy-Environmental Kuznets Curve for Latin America and the Caribbean. Renewable and Sustainable Energy Reviews, v.60, p.1343-1350,2016. doi: https://doi.org/10.1016/j.rser.2016.03.029.

PASTÉN R., SAES R., MARÍN R.CDoes energy use cause economic growth in Latin America?. Applied Economics Letters, v.22, n.17,p.1399-1403,2015. doi: https://doi.org/10.1080/13504851.2015.1034834.

PESARAN H.,. A Simple Panel Unit Root Test in the Presence of Cross Section Dependence. Cambridge Working Papers in Economics 0346, Faculty of Economics (DAE), University of Cambridge, $2003 . \quad$ URL: http:/www.econ.cam.ac.uk/research-files/repec/cam/pdf/cwpe0346.pdf.

PESARAN M.H., General diagnostic tests for cross section dependence in panels. The University of Cambridge, Faculty of Economics. Cambridge Working Papers in Economics, n.435, 2004. URL: http://ftp.iza.org/dp1240.pdf.

PESARAN M.H., SHIN Y., SMITH R.P.,Pooled mean group estimation of dynamic heterogeneous panels. Journal of American Statistical Association, v.94, n.446, p. 621-634,1999. URL: http://www.jstor.org/stable/2670182.

PESARAN M.H., SMITH R., Estimating long-run relationships from dynamic heterogeneous panels. Journal of Econometrics, v.68, n.1, p.79-113,1995. https://doi.org/10.1016/0304-4076(94)01644-F. 
ROCHER C.L., Linear and nonlinear relationships between interest rate changes and stock return: International evidence.

Universidad de Valencia, Working Paper v.17, n.16, 2017 URL: https://www.uv.es/bfc/TFM2017/16\%20Carlos\%20Lopez\%20Rocher.pdf.

RODRÍGUEZ-CABALLERO C.V., VENTOSA-SANTAULÀRIA D., Energy-growth long-term relationship under structural breaks. Evidence from Canada, 17 Latin American economies and the USA. Energy Economics, v.61, p.121134.,2017. doi: https://doi.org/10.1016/j.eneco.2016.10.026.

SADORSKY P., Energy consumption, output and trade in South America. Energy Economics, v.34, n2., p.476-488,2012. doi: https://doi.org/10.1016/j.eneco.2011.12.008.

SBIA R., SHAHBAZ M., HAMDI H., A contribution of foreign direct investment, clean energy, trade openness, carbon emissions and economic growth to energy demand in UAE. Economic Modelling, v.36, p.191-197,2014. doi: https://doi.org/10.1016/j.econmod.2013.09.047.

SEBRI C.M., BEN-SALHA O., On the causal dynamics between economic growth, renewable energy consumption, $\mathrm{CO} 2$ emissions, and trade openness: Fresh evidence from BRICS countries. Renewable and Sustainable Energy Reviews, v.39, p.14-23,2014. doi: https://doi.org/10.1016/j.rser.2014.07.033.

SHAHBAZ M., NASREEN S., LING C.H., SBIA R., Causality between trade openness and energy consumption: What causes what in high, middle and low-income countries. Energy Policy, v.70, p.126-143,2014.doi: https://doi.org/10.1016/j.enpol.2014.03.029.

SHIN Y., YU, B., GREENWOOD-NIMMO M., Modelling asymmetric cointegration and dynamic multipliers in a nonlinear ARDL framework. In Festschrift in Honor of Peter Schmidt, p.281-314,2014. doi: https://doi.org/10.1007/978-1-4899-80083_9.

TISSOT R., Latin America's Energy Future. Inter-American Development Bank (IDB),p.1-46,2012. URL: https://publications.iadb.org/handle/11319/5709?localeattriute=en\&localeattri bute=es\&.

WOOLDRIDGE J.M., Econometric analysis of cross section and panel data. The MIT Press Cambridge, Massachusetts London, England, 2002. URL: https://jrvargas.files.wordpress.com/2011/01/wooldridge j_2002_econometric_analysis_of_cross_section_and_panel_data.pdf.

World Bank Open Data., 2019. URL:http://www.worldbank.org/.

YORK R. Do alternative energy sources displace fossil fuels?. Nature Climate Change, v.2, n.6, p.441-443,2012. doi:10.1038/nclimate1451.

ZAHONOGO P., Trade and economic growth in developing countries: Evidence from sub-Saharan Africa. Journal of African Trade, v.3, n.1-2, p.41-56, 2016.doi:https://doi.org/10.1016/j.joat.2017.02.001. 


\section{Appendix}

Table 5 - Hausman test.

\begin{tabular}{|c|c|c|c|c|}
\hline Variables & b. Fixed & Random & (b-B) Difference & $\operatorname{Sqrt}\left(\operatorname{diag}\left(V_{-} b-V-B\right)\right)$ S.E. \\
\hline DLnY & 0.6973 & 0.8162 & -0.1188 & 0.0822 \\
\hline DLnREC & -0.4224 & -0.4611 & 0.0387 & 0.0226 \\
\hline DLnTR & 0.2946 & 0.1886 & 0.1059 & 0.0272 \\
\hline LnFOC & -0.3619 & -0.0786 & -0.2833 & 0.0306 \\
\hline LnY & 0.7441 & 0.0477 & 0.6963 & 0.1080 \\
\hline LnREC & -0.0426 & 0.0032 & -0.0458 & 0.0430 \\
\hline LnTR & 0.1652 & 0.0420 & 0.1232 & 0.0538 \\
\hline $\mathrm{Chi}^{2}(7)$ & $95.79 * * *$ & & & \\
\hline
\end{tabular}

Notes: $* * *$ denotes statistically significant at $1 \%$ level; (Ln and DLn) denote variables in natural logarithms and first-differences of logarithms respectively; The Stata command Hausman (with the options, sigmamore alleqs constant) was used.

Table 8 - Hausman test from robustness check.

\begin{tabular}{ccc}
\hline MG vs PMG & PMG vs FE & MG vs FE \\
\hline $\mathrm{Chi}^{2}(21)=-36.37$ & $\mathrm{Chi}^{2}(25)=-374.58$ & $\mathrm{Chi}^{2}(25)=-275.03$ \\
\hline
\end{tabular}

Notes: $* * *$ denotes statistically significant at $1 \%$, level; Hausman results for H0: difference in coefficients not systematic; the Stata commands xtpmg, and Hausman (with the option alleqs) was used.

Table 9 - Specification tests from robustness check.

\begin{tabular}{|c|c|c|c|c|}
\hline \multirow{2}{*}{ Statistics } & Modified Wald test & Wooldridge test & $\begin{array}{l}\text { Pesaran's } \\
\text { test }\end{array}$ & $\begin{array}{c}\text { Breusch and Pagan Lagrangian Multiplier } \\
\text { test }\end{array}$ \\
\hline & $\begin{array}{l}\operatorname{chi}^{2}(14)= \\
421.28 * * *\end{array}$ & $\begin{array}{l}\mathrm{F}(1,13)= \\
17.470 * * *\end{array}$ & -1.166 & n.a \\
\hline
\end{tabular}

Notes: $* * *$ denotes statistically significant at $1 \%$ level; $\mathrm{H} 0$ of Modified Wald test: sigma(i)^2 ${ }^{\wedge}$ sigma 2 for all $\mathrm{i}$; H0 of Wooldridge test: no firstorder autocorrelation; H0 of Pesaran's test: residuals are not correlated; H0 of Breusch and Pagan Lagrangian Multiplier test: no dependence between the residuals; (n.a) denotes not available. 